

\title{
Espaço-Corpo e a (Re)elaboração das Transmasculinidades e Identidades de Homens Trans
}

\author{
El Cuerpo-Espacio y la (Re)elaboración de Transmasculinidades e Identidades \\ de los Hombres Trans
}

\author{
Body-Space and the (Re)elaboration of Transmasculinities and Identities of \\ Trans Men
}

\section{Resumo}

O presente artigo tem por objetivo compreender o movimento de (re)elaboração das transmasculinidades e das identidades a partir da corporeidade de homens trans. Para tanto, a trajetória de inteligibilidade do fenômeno eleito foi delineada a partir de 10 entrevistas com homens trans que vivenciam ou vivenciaram os espaços educacionais de nível superior. Os resultados obtidos apontam para a necessidade de considerar que tanto o espaço quanto as identidades (de gênero) e os corpos são (re)elaborados em um processo aberto e contínuo, através dos quais novas identidades - transitórias e instáveis, são (re)elaboradas a todo instante no espaço-tempo, mediante as relações de poder.

Palavras-Chave: Espaço; Corpo; Transmasculino; Identidade; Corporeidade.

\section{Resumen}

Este artículo tiene como objetivo comprender el movimiento de (re) elaboración de transmasculinidades e identidades desde la corporalidad de los hombres trans. Por tanto, la trayectoria de inteligibilidad del fenómeno elegido, se esbozó a partir de 10 entrevistas a hombres trans que, en su condición de estudiantes, estuvieron o han estado presentes en espacios de educación superior. Los resultados obtenidos apuntan a la necesidad de considerar que tanto el espacio como las identidades y cuerpos (de género) son (re) elaborados en un proceso abierto y continuo, a través del cual nuevas identidades - transitorias e inestables, son (re) elaboradas a cada momento en el espacio-tiempo, a través de las relaciones de poder.

Palabras-Clave: Espacio; Cuerpo; Transexual; Identidad; Corporalidad.

\begin{abstract}
This article aims at understanding the movement of (re) elaboration of transmasculinities and identities from the corporealities of trans men. To achieve our objective, the trajectory of intelligibility of the chosen phenomenon was delimited from 10 interviews with trans men who were experiencing or had experienced higher-level educational spaces. The results obtained point to the need to consider that both space and (gender) identities and bodies are (re) elaborated in an open and continuous process, through which new identities - transitory and unstable, are (re) elaborated at every moment in space-time, through power relations.
\end{abstract}

Keywords: Space; Body; Transmasculine; Identity; Corporeality. 
em qualquer ordem de gênero de uma sociedade. Em reconhecimento desse fato, tem-se tornado comum falar de 'masculinidades'". Ao definir masculinidade(s), Connell (1995), alerta sobre a problemática de conceber o conceito enquanto uma mistura de elementos identitários e práticas, sendo necessário a compreensão do termo constituído por relações de poder. Isto corrobora com o argumento de Januário (2016), ao destacar que as masculinidades não podem ser compreendidas simplesmente enquanto sinônimo de identidades, mas enquanto múltiplas práticas dinâmicas que variam no espaço-tempo.

O conceito de masculinidade(s) proposto por Connell (1995) pode ser melhor compreendido, segundo a autora, quando o termo 'configuração de prática' é entendida simplesmente como o 'fazer' e não como 'aquilo que é previsto socialmente', ou seja, a 'prática' não possui fronteiras delimitadas para sua expressão, podendo ser tanto reproduzida como produzida socialmente, segundo a racionalidade da ação e de um contexto histórico (e geográfico). A 'posição dos homens' se refere às 'relações sociais e aos corpos', neste caso, adultos, sendo as masculinidades tanto corporificadas quanto sociais. Por fim, as 'estruturas de relações de gênero' são entendidas neste contexto indo além de meros papéis sociais.

Mais do que o próprio conceito, é importante compreender como a masculinidade é constituída, sendo para Connell (1995) um processo individual, mas também coletivo. O que não é diferente quando se trata das transmasculinidades, uma vez que para Ávila (2014), as transexperiências tanto são individuais quanto coletivas.

A produção teórica sobre as masculinidade(s) é ampla e diversificada, com diferentes objetivos, desde teorias críticas às teorias não-críticas, sendo possível encontrar também estudos que justificam o 'masculino tradicional', os quais não realizam uma criticidade sobre o termo (ALVES, 2005). Neste sentido, para nos debruçarmos numa perspectiva crítica relacionada às masculinidades, recorremos especificamente à Connell (1995; 2003), Kimmel (1998), Sigusch (1998), Fialho (2006), Botton (2007), Schilt e Westbrook (2009), Connell e Messerschmidt (2013) e Januário (2016). Entendemos que estas referências são essenciais para uma construção do conhecimento relacionada à (re)elaboração das transmasculinidades, bem como sua relação com as vivências espaciais dos homens trans entrevistados.

$\mathrm{O}$ conceito de masculinidade(s) enfrenta contradições de teóricos que acreditam numa crise da masculinidade e entre aqueles que acreditam no seu fator de dominação (BOTTON, 2007). Segundo Botton (2007), pelo viés de dominação, está presente a virilidade e as violências tanto físicas quanto simbólicas. Já pelo viés da crise, está presente uma vitimização e sensibilidade por parte dos homens no processo de elaboração da sua masculinidade. Acreditar numa crise da masculinidade, segundo Januário (2016), supõe que ela possui caráter fixo e que se constitui enquanto exclusiva dos homens, assim, vivenciados somente por eles. Embora tais abordagens sejam distintas, estes embates são importantes pois se configuram enquanto avanços tanto teóricos quanto sociais no que concerne as discussões sobre masculinidades no campo científico.

Corroboramos com a autora quando afirma sobre a existência da dominação

Adelaine Ellis Carbonar dos Santos, Marcio Jose Ornat 
masculina, segundo um poder simbólico imbricado nas relações sociais, de modo mascarado, camuflado e naturalizado. Considerando, assim, a noção de masculinidade como uma construção social, histórica e geográfica, com caráter múltiplo e mutável, tendo a dominação masculina elementos de opressão não somente relacionada às mulheres, mas também entre os próprios homens.

Neste sentido, há múltiplas formas de vivenciar as masculinidades, as quais se encontram imbricadas por relações de poder. É mediante a interseccionalidade que Connell (2003, p. 114) elabora uma análise sobre as masculinidades, pois, "las masculinidades de los hombres de raza blanca, por ejemplo, se construyen no sólo en relación con las mujeres blancas, sino también con los hombres negros". Para a autora, não é possível compreender a estrutura social sem considerar o gênero enquanto um elemento fundamental desta estrutura. Entendemos então que as masculinidades elaboradas por homens trans também estão imbricadas por relações de poder (FOUCAULT, 1988), não só em relação aos homens ou mulheres cis, mas também com outros homens e mulheres trans.

Nesta perspectiva interseccional, Connell (2003) afirma que as masculinidades são frequentemente divididas e contraditórias, sofrendo alterações histórico-espaciais, podendo ser classificadas como: hegemônicas; cúmplices; subordinadas; marginais. Contudo, para evitar simplificações de situações como considerar a unificação de uma masculinidade branca, por exemplo, ou uma única masculinidade negra, o reconhecimento de múltiplas masculinidades torna-se uma premissa importante.

As masculinidades hegemônicas podem ser entendidas enquanto masculinidades de referencial dominante ideal em dada sociedade e em determinado contexto histórico, não podendo ser compreendidas somente como a prática de agressões físicas (CONNELL, 2003). De acordo com Kimmel (1998, p. 105), a masculinidade hegemônica está em oposição à outras desvalorizadas, isto é, a relação entre masculinidades hegemônicas e subalternas se originam mediante interações desiguais e recíprocas. Para o autor, tais interações relacionais podem ser compreendidas a partir de três pressupostos: $\mathrm{O}$ primeiro é conceber as masculinidades enquanto construtos sociais, não-essencialistas e determinadas biologicamente, mas que "(1) variam de cultura para cultura, (2) variam em qualquer cultura no transcorrer de um certo período de tempo, (3) variam em qualquer cultura através de um conjunto de outras variáveis, outros lugares potenciais de identidade e, (4) variam no decorrer da vida de qualquer homem individual".

O segundo pressuposto, conforme Kimmel (1998), leva-nos a compreender que as relações de poder estão presentes na constituição das masculinidades, principalmente no que refere-se às desigualdades de gênero (interrelacional, entre homens e mulheres) e nas desigualdades de raça, etnicidade, sexualidade, idade, etc (intrarelacional, entre homens), sendo o sexismo e a homofobia elementos do processo de constituição das masculinidades, como afirmado pelo autor e, posteriormente, com mais afinco presente nas discussões de Welzer-Lang (2001) sobre a dominação masculina, a qual produz uma homofobia mediante ameaças voltadas aos homens para que obtenham os padrões de virilidade. Sobre este ponto, nós incluiríamos também como elemento neste processo de constituição das masculinidades a transfobia 
voltado à homens trans, principalmente àqueles que não possuem uma passabilidade condizente com tais padrões estabelecidos.

Por fim, o terceiro e último pressuposto considera, segundo Kimmel (1998), que as relações de poder são por vezes invisíveis para aqueles que detém uma masculinidade hegemônica, sendo perceptível para os homens com masculinidades subalternas, os quais são afetados pela violência.

Além das masculinidades hegemônicas, propostas por Connell (2003), a autora argumenta que existem masculinidades cúmplices, as quais são elaboradas por homens que se beneficiam ao obter vantagens de subordinação em relação às mulheres mediante a estrutura do patriarcado, mas que não 'praticam' a masculinidade hegemônica. Um exemplo que Connell (2003) estabelece para explicar esta cumplicidade está nas relações estreitas dos homens com as mulheres, como o casamento e a paternidade. Assim, mesmo que tais relações estejam baseadas no respeito, muitos homens se aproveitam dos privilégios do patriarcado.

Outro tipo de masculinidade discutida por Connell (2003) refere-se às masculinidades subordinadas. Estas dizem respeito às relações de dominação entre os próprios homens a partir da heteronormatividade. Assim, segundo a autora, existem relações de poder entre homens heterossexuais e homossexuais, ao passo que estes últimos se encontram numa posição subordinada em relação aos primeiros, devido a 'aproximação' com a feminilidade, sendo possível, segundo Connell (2003, p. 119), "[...] detectarse cómo los límites se confunden simbólicamente con la feminilidad".

Entendemos que estas masculinidades subordinadas também dialogam com o modelo explicativo proposto por Sigusch (1998). Segundo ele, uma transexualidade que envolve a redesignação cirúrgica do sexo se diferencia daquilo que o autor chama de neossexualidades ${ }^{3}$, pois teria mais o significado de um neogênero que se auto-fixa do que uma nova forma de neossexualidade. Para ele, a principal característica neológica da transexualidade seria a sua projeção daquilo que o autor chama de cissexualismo ${ }^{4}$, uma contraparte lógica, mesmo que ambígua. Para este autor, se existe um trans, deve haver um cis, um 'ao-lado-deste', também. Portanto, ao afirmar que sexo e gênero são composições culturais e que são psicossocialmente comunicadas, as existências transexuais colocam em questão a referência de normalidade de sexo e gênero das pessoas cissexuais, pois inquestionavelmente e naturalmente as categorias trans e cis andam juntas.

A masculinidade homossexual é a mais evidente das masculinidades subordinadas, mas não a única, sendo que os homens heterossexuais também podem elaborar suas masculinidades de modo subordinado (CONNELL, 2003). Podemos incluir também nesta perspectiva subordinada as masculinidades de homens trans que mesmo elaborando suas masculinidades em conformidade com a cisgeneridade ${ }^{5}$, mediante passabilidade ou não, podem sofrer discriminações pelo fato de terem nascidos biologicamente constituídos pelo sistema de órgãos femininos e, consequentemente, estarem

$3 \mathrm{O}$ autor identifica como neossexualidades as práticas sadomasoquistas, fetichistas e transgender.

4 Estas discussões foram desenvolvidas em Sigusch (1991a; 1991b; 1995a; 1995b). 
simbolicamente próximos à feminilidade.

Segundo Schilt e Westbrook (2009), uma performance de gênero que não corresponde ao sexo biológico pode ser compreendida enquanto uma ameaça ao funcionamento da heterossexualidade, e assim, tanto homens quanto mulheres cisgênero tentam reparar estas rupturas entre sexo, gênero, prática sexual e desejo (BUTLER, 2003), criando normas de gênero que coisificam, tornam material o gênero e a diferença sexual. Segundo as autoras, estas táticas de reparação das rupturas entre sexo, gênero, prática sexual e desejo simultaneamente negam a autenticidade da vivência de mulheres e homens trans, com suas identidades sexuais, e reafirmam que a heterossexualidade, com sua atração ao sexo oposto entre corpos diferentes é a existência humana normal, natural e a desejável.

Como afirmado pelas autoras, atrás da persistência das desigualdades de gênero há esquemas culturais que naturalizam o sistema binário de gênero, formado por duas 'posições' que advém da biologia, relacionados a cromossomos e genitália. São estes esquemas que são constituintes e constituem os padrões de relações sociais entre homens e mulheres, entre homens e homens, entre homens e homens trans, e entre homens trans e homens trans. Para Schilt e Westbrook (2009) são estes esquemas que moldam as normas de masculinidade e feminilidade, naquilo que é permitido em termos de ser 'homem' e 'mulher'. Em diálogo com Connell (1987) e Schippers (2007) as autoras afirmam que esta ordem de gênero é hierárquica, significando que atribui um valor mais alto para as masculinidades em detrimento das feminilidades, e para algumas masculinidades em detrimento de outras.

Para Connell (2003), os tipos de masculinidades até então apresentadas referem-se às interações relacionadas ao gênero (e sexualidades), sendo que tais relações com outras categorias identitárias como a raça e a classe resultam em novas configurações de masculinidades de modo interseccional. Assim, as masculinidades marginalizadas dizem respeito às relações de dominação e subordinação entre homens, a partir da classe social e da raça, sendo tal marginalização relativa à autorização do grupo dominante mediante masculinidade hegemônica. Um ponto importante é de que a relação 'marginalização e autorização' também está presente nas masculinidades subordinadas (CONNELL, 2003).

Tais classificações das masculinidades propostas por Connell não foram isentas de críticas, em especial as masculinidades hegemônicas (JANUÁRIO, 2016). Para esta autora, o conceito de masculinidade hegemônica é criticado por alguns autores (MATOS, 2000; ALVES, 2005; FIALHO, 2006), visto que o conceito por si só não traz avanços significativos nas discussões sobre a temática ao abordar sobre a hegemonia. Além disso, é questionado pelos autores se a posição conferida pela masculinidade hegemônica é desejada pelas outras formas de masculinidades. Neste último caso, Januário (2016) destaca que não acredita na busca do movimento feminista ou LGBT+ pela posição

5 Podemos afirmar, com base em Schilt e Westbrook (2009), que a cisgeneridade é uma condição da pessoa que têm uma correspondência entre o gênero ao qual foram designados no momento do nascimento (ou antes dele), o seu corpo e a sua identidade pessoal. 
hegemônica, mas pela luta da 'legitimidade, igualdade e equidade'.

As críticas voltadas às discussões de masculinidades propostas nos estudos de Connell fizeram com que ela, em conjunto com o James W. Messerschmidt, publicassem um texto intitulado 'Masculinidades Hegemônicas: repensando o conceito', o qual refletem sobre as discussões até então formuladas, realizando um diálogo com os autores críticos mediante três pressupostos: reafirmação, rejeição e reformulação das discussões. Assim, Connell e Messerschmidt (2013) reafirmam algumas considerações iniciais como a existência da multiplicidade das masculinidades, a confirmação do conceito de hegemonia e a possibilidade de transformação, mas também afirmam que outras considerações devem ser rejeitadas como conceber a hierarquia enquanto única dimensão e características de gênero. Ainda, os autores realizam uma reformulação de alguns pontos contraditórios do conceito de masculinidade hegemônica, pois o mesmo se trata de um conceito contestado.

A reformulação do conceito de masculinidade hegemônica, de acordo com os autores, é realizada mediante: (1) a 'compreensão integral da hierarquia de gênero', com a devida atenção às práticas das mulheres e as relações de poder; (2) 'o reconhecimento da geografia das masculinidades', com destaque para as questões interseccionais e escalares, analisadas desde o nível local (famílias), regional (aspectos socioculturais) e global (arenas transnacionais); (3) a importância da encorporação masculina para a identidade e o comportamento ${ }^{6}$ e; (4) 'as contradições e possibilidades de práticas com vistas à democracia dos gêneros', relacionadas ao processo de elaboração das masculinidades hegemônicas.

Mesmo com numerosas críticas não se pode negar que a concepção de múltiplas masculinidades e o conceito de masculinidade hegemônica contribuiu para as mais diversas pesquisas científicas sobre tais temas, aplicados em distintos contextos histórico-sociais, abandonando de vez o determinismo biológico (CONNELL; MESSERSCHMIDT, 2013). Para os autores, o conceito de masculinidade hegemônica se constitui enquanto uma ferramenta para a compreensão de um determinado fenômeno social e não como causa ou obrigação de explicar tudo.

Enquanto uma ferramenta de compreensão, o conceito de masculinidade hegemônica nos parece ser útil para a análise das transmasculinidades, que podem ser entendidas enquanto masculinidades subordinadas, na proposta de Connell (2003), em relação às masculinidades hegemônicas. Entretanto, a sua classificação hierárquica enquanto masculinidades subordinadas não podem ser entendidas como fixas ou fundantes, mas que possuem múltiplas formas de elaboração.

Compreendemos então por transmasculinidades as masculinidades elaboradas por homens trans, partindo da premissa da existência de múltiplas transmasculinidades, podendo ser "[...] masculinidades alternativas, mesmo estando incluídas em práticas de dominação, subordinação e marginalização" (ÁVILA, 2014, p. 15). Podemos então pensar as transmasculinidades a partir do conceito reformulado de masculinidades hegemônicas sobre encorporação

6 Este ponto do conceito reformulado de masculinidade hegemônica realizado por Connell e Messerschmidt (2013) será discutido mais à frente na compreensão das (trans)masculinidades. 
masculina (CONNELL; MESSERSCHMIDT, 2013), frente às críticas recebidas anteriormente por Connell.

Encorporação foi o termo utilizado para traduzir a palavra embodiment ${ }^{7}$ empregada pelos autores. Assim, a partir deste ponto, utilizaremos a palavra corporeidade ao se referir à embodiment, termo empregado por Connell e Messerschmidt (2013). Como evidenciado nesta publicação, as práticas trans demonstram a necessidade de uma compreensão mais profunda sobre os processos que permeiam a corporeidade na masculinidade hegemônica. Entretanto, alertam os autores, a associação de práticas trans em relação à hegemonia pode não se configurar enquanto um campo seguro, visto a complexidade de compreender tais práticas dentro de um modelo bipolar de construção social.

Ao recorrer à Connell (2002), Connell e Messerschmidt (2013) argumentam que a compreensão da relação entre corporeidade e hegemonia só pode ser conquistada ao considerarmos que os corpos são tanto objetos quanto agentes da prática social. Ou seja, as práticas corporais estão relacionadas com a elaboração de práticas sociais. Para os autores, é preciso destacar tanto a importância do processo de corporeidade masculina na elaboração das identidades e comportamentos dos homens (habilidades no esporte, por exemplo, são indicadores sociais de masculinidade), quanto a importância das relações entre corporeidades e contextos sociais. Assim, mesmo que homens trans possam não elaborar suas masculinidades numa perspectiva contrahegemônica, elas também constituem a dinâmica hierárquica das masculinidades oscilando entre as classificações conneliana (hegemônicas, cúmplices, subordinadas e marginalizadas) (ÁVILA, 2014).

Segundo Ávila (2014), a elaboração das transmasculinidades está ligada às relações hierárquicas entre homens trans, e entre homens trans e homens cis ${ }^{8}$, mulheres e o campo da saúde, que diz respeito à uma estrutura escalar da transexualidade: "Parece ser 'mais' trans quem já iniciou a transição, quem toma hormônios, quem fez mastectomia, quem tem uma aparência mais masculina. É como se esses fossem os transhomens mais 'legítimos' para falar de si enquanto trans" (ÁVILA, 2014, p. 213). Neste sentido, é como se as transmasculinidades, mesmo sendo classificadas enquanto masculinidades subordinadas numa perspectiva conneliana, apresentem variadas formas de elaboração desta subordinação. Ao passo que os homens trans buscam ou não os padrões masculinos da cisheteronormatividade, podem estar mais próximos ou mais afastados da masculinidade hegemônica.

Poderíamos então falar de transmasculinidades subordinadas-hegemônicas, transmasculinidades subordinadas-subordinadas, transmasculinidades subordinadas-marginalizadas ou ainda, transmasculinidades subordinadascúmplices, relacionadas na elaboração das identidades e nas masculinidades de homens trans. Assim, a figura a seguir (Figura 1) apresenta um fluxograma das

7 Tradução do texto "Masculinidades Hegemônicas: repensando o conceito" realizada por Felipe Bruno Martins Fernandes.

8 Para Schilt e Westbrook (2009), o prefixo Cis tem o significado "do mesmo lado". Para elas, o prefixo cis complementa o prefixo trans, entendido como 'através' ou 'sobre'. Segundo estas autoras, o termo "cisgênero' substitui os termos não-transgênero ou 'homem bio' / 'mulher bio'.

Adelaine Ellis Carbonar dos Santos, Marcio Jose Ornat 
relações presentes na (re)elaboração das transmasculinidades, segundo a ideia conneliana de classificação das masculinidades, bem como a necessidade da corporeidade (embodiment) masculina para a identidade e o comportamento, como apresentado por Connell e Messerschmidt (2013).

Figura 1 - Fluxograma das relações presentes nas transmasculinidades ${ }^{9}$.

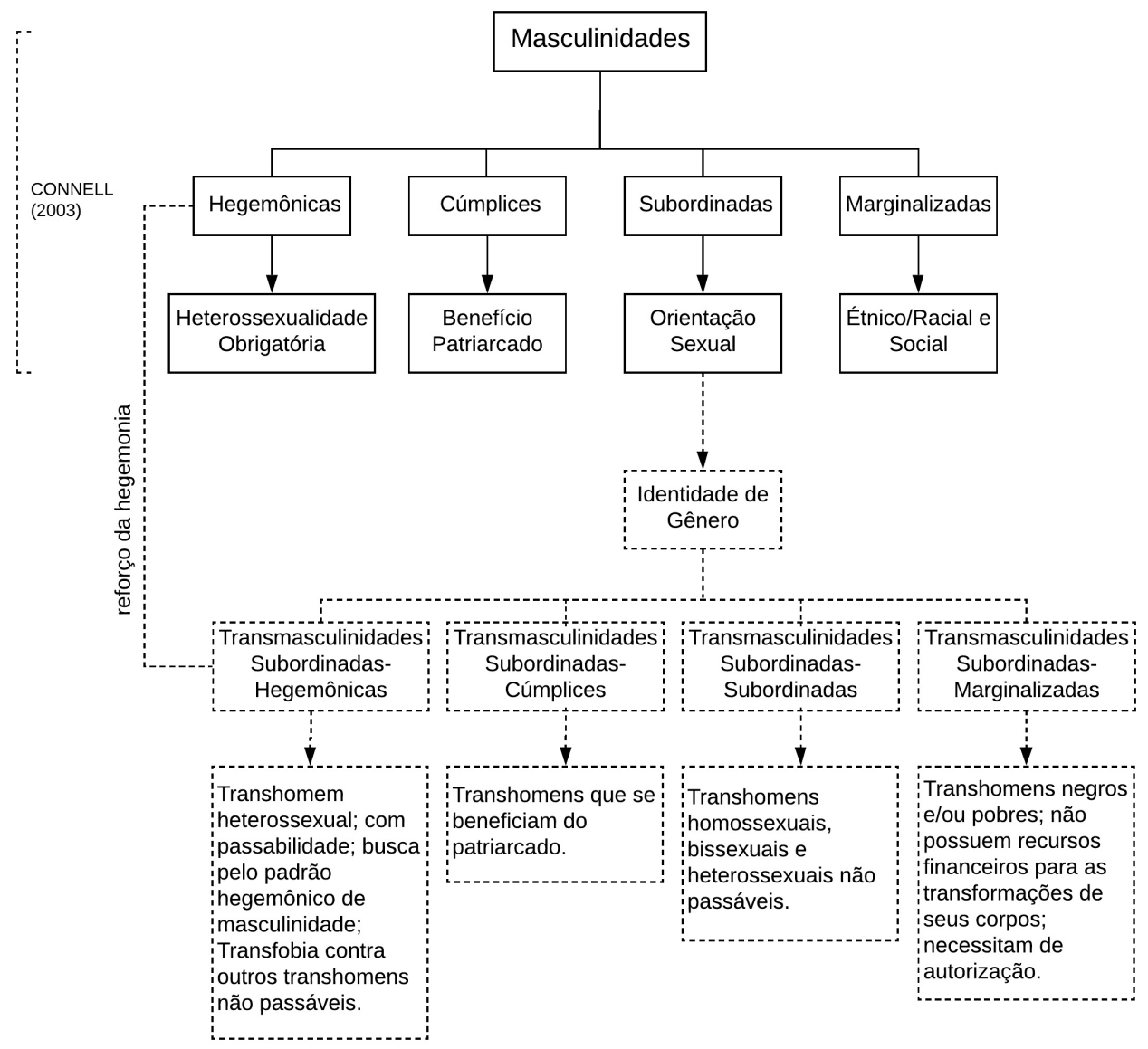

Fonte: Adaptado de Connell (2003). Organização: Santos (2020).

- As transmasculinidades subordinadas-hegemônicas: são as masculinidades (re)elaboradas por homens trans heterossexuais (lembrando que a masculinidade hegemônica tem por premissa a heterossexualidade obrigatória), os quais buscam os padrões de masculinidade ideal mediante recursos financeiros na conquista da passabilidade e, por isto mesmo, podem praticar transfobia contra pessoas trans (incluindo as mulheres) não passáveis. Estes padrões podem ser representados desde atitudes machistas e discriminatórias até as cirurgias de transgenitalização.

- As transmasculinidades subordinadas-cúmplices: sua compreensão é semelhante a elaborada para as masculinidades cúmplices na perspectiva de Connell (2003). Como destacado pela autora, poucos homens cis conquistam a masculinidade hegemônica, e assim, um número ainda mais reduzido de homens trans a atinge. Contudo, os homens trans podem se beneficiar dos

9 Este fluxograma possui a intenção de explicitar uma tipologia analítica e não uma tipologia absoluta, uma vez que as identidades estão em constante fluxo (HALL, 2005 [1992]; CASTELLS, 1999 [1997]; DUBAR, 1997; WOODWARD, 2000; SILVA, 2000). 
privilégios do patriarcado, assim como os homens cis.

- As transmasculinidades subordinadas-subordinadas: são masculinidades (re)elaboradas não somente por homens trans homossexuais e bissexuais, mas também por homens trans heterossexuais que não possuem sua passabilidade de acordo com os padrões cisheteronormativos. Desta forma, além de possuírem a vagina, sua corporeidade está muito próxima à feminilidade - seja pela orientação sexual dissidente, mesmo que tenha passabilidade; seja pela passabilidade quase nula nos casos de homens trans heterossexuais - tendo uma posição de subordinação frente às transmasculinidades subordinadashegemônicas.

- As transmasculinidades subordinadas-marginalizadas: são as masculinidades (re)elaboradas por homens trans negros e/ou pobres. As questões de passabilidade estão diretamente ligadas aos recursos econômicos que possuem para obter as transformações desejáveis de seus corpos. Assim como nas masculinidades marginalizadas discutidas por Connell (2003), a marginalização deste grupo está condicionada a autorização do grupo dominante. Estas transmasculinidades subordinadas-marginalizadas comprovam o argumento de Connell (2003), quando afirma que a marginalização e a autorização também estão presentes nas masculinidades subordinadas.

Como podemos evidenciar, estas relações de dominação e subordinação que constituem as transmasculinidades podem ser compreendidas pelo conceito de passabilidade, além das questões de gênero, raça, classe e sexualidade, apontado por Connell (2003). Para Lanz (2014), a passabilidade seria o reconhecimento da sociedade que determinada pessoa trans está em conformidade com as normas vigentes de gênero. Em outras palavras, "passabilidade traduz o quanto uma pessoa transgênera se parece fisicamente, se veste, fala, gesticula e se comporta de acordo com os estereótipos do gênero oposto ao que lhe foi consignado ao nascer" (p. 129). 'Passar' se constitui enquanto uma busca por parte das pessoas trans, conferindo à passabilidade um status tanto de segurança referente às questões de transfobia, quanto de contentamento ao ter a sua identidade de gênero reconhecida e respeitada (LANZ, 2014).

A passabilidade, segundo Lanz (2014), possui a função de legitimar a identidade de gênero da pessoa trans a partir do julgamento do outro, o qual possui a autoridade de validação da mesma, e por isso mesmo acarretando uma insegurança por parte das pessoas trans. Esta insegurança reitera a rigidez dos critérios estabelecidos de passabilidade, não obstante, formulados pela própria população trans, sendo critérios de masculinidade e feminilidade tão rígidos que nem pessoas cis conseguem alcançá-los. Além da insegurança, paira o medo que estas pessoas sentem ao 'não passar' aos olhos não somente no convívio social amplo, mas também dentro do círculo trans (LANZ, 2014). Neste sentido, não seria uma estrutura escalar da transexualidade como argumentado por Ávila (2014), mas uma hierarquia entre quem é mais passável ou não socialmente.

Vale ressaltar que 'passar' pode não ser o propósito de uma pessoa trans inclusive podendo até mesmo contestar os padrões de passabilidade - mas que mesmo assim, ela está inserida num contexto social exigente com os padrões 
de transmasculinidades e transfeminilidades. Como evidenciado, a passabilidade também pode estar relacionada aos recursos econômicos para a 'construção' dos corpos. Ou seja, procedimentos cirúrgicos ou estéticos, terapias hormonais, consultas médicas, terapias psicológicas e acompanhamento jurídico, por exemplo, podem ser conquistados mais ou menos rapidamente, mediante condições econômicas. Isto demonstra a necessidade de compreensão da corporeidade (embodiment) masculina na elaboração das masculinidades de homens trans como sugeriu Connell e Messerschmidt (2013).

\section{Corpo e a (Re)Elaboração das Identidades e Masculinidades de Homens Trans}

Devido as identidades e (trans)masculinidades serem múltiplas e interseccionadas, existem variadas possibilidades de (re)elaboração dessas masculinidades, dentre elas as transmasculinidades, que por sua vez, também possuem variadas formas de relações espaço-temporais, mesmo que se constituam enquanto subordinadas às masculinidades hegemônicas numa perspectiva de Connell (2003). Desta forma, a partir das entrevistas realizadas com homens trans participantes da pesquisa, podemos compreender como se estabelecem as identidades e as transmasculinidades deste grupo. Para tanto, partimos da ideia de conceber o corpo enquanto espaço, pois, o corpo é socialmente e geograficamente posicionado, não sendo possível compreendêlo fora do contexto espaço-temporal (SILVA; ORNAT, 2016).

Silva (2013), argumenta que a compreensão do corpo nas discussões realizadas pela Geografia feminista estava ausente pelo menos até o final do século XX, ganhando paulatinamente importância no campo científico geográfico a partir deste período. Para a autora, além da perspectiva feminista, a nova geografia cultural, fenomenologia e queer, problematizavam a relação corpo-espaço numa vertente geográfica, a partir do rompimento da oposição entre corpo e mente. Este rompimento possibilitou compreender as identidades corporais enquanto fluídas e instáveis, transformando o entendimento do corpo, antes como imutável, para a compreensão de corporeidade que pressupõe movimento. A corporeidade, neste sentido, é utilizada pela ciência geográfica na assimilação da fluidez e nas transformações corporais, deixando de lado o determinismo biológico (SILVA, 2013).

Mediante a ideia de corporeidade (embodiment) podemos compreender como homens trans (re)elaboram suas identidades e transmasculinidades e quais as relações que ambas estabelecem com suas vivências espaciais, pois, como destaca Silva e Ornat (2016, p. 63) "(...) o corpo se constitui na maneira como as pessoas se conectam com outros espaços e experimentam o espaço". Concebendo os corpos enquanto objetos discursivos que se alteram de acordo com o espaço-tempo (SILVA, 2013), destacamos novamente que as identidades e as transmasculinidades não são sinônimos, mas que estas últimas são práticas dinâmicas constituídas por relações de poder que também variam espacialmente e temporalmente (CONNELL, 1995; JANUÁRIO, 2016). Portanto, a partir da análise de conteúdo do discurso dos homens trans que vivenciam ou vivenciaram os espaços educacionais de nível superior, 
Espaço-Corpo e a (Re)elaboração das Transmasculinidades e Identidades de

Homens Trans

evidenciamos como estes sujeitos (re)elaboram suas identidades e transmasculinidades das entrevistas realizadas com homens trans. O gráfico 1 apresenta as categorias discursivas da categoria espacial 'Corpo'.

Gráfico 1 - Categorias Discursivas da Categoria Espacial - 'Corpo'.

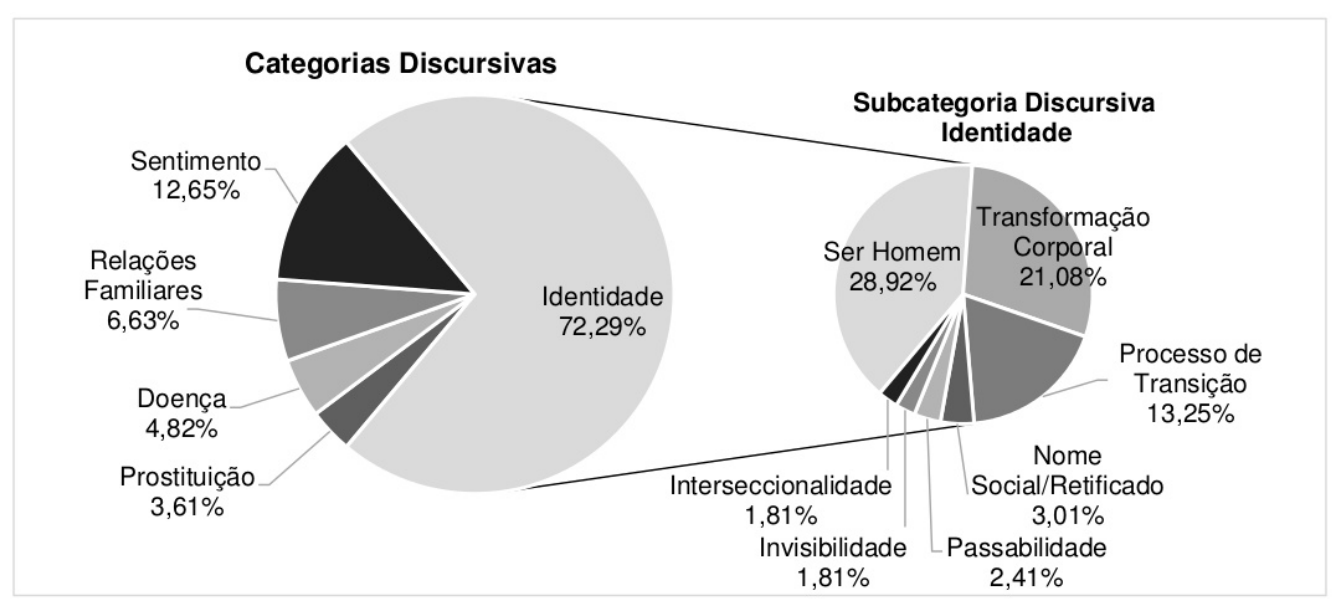

Fonte: Entrevistas realizadas com homens trans que vivenciam / vivenciaram os espaços educacionais de nível superior, entre os dias 14 de janeiro de 2016 a 07 de abril de 2018. Organização: Santos (2020).

Como o próprio gráfico evidencia, compreender o corpo enquanto espaço é pressupor que existem variadas relações que o constitui, desde questões físicas até questões psicológicas, constatando que não podemos compreender corpo e mente separadamente. Indo além, não podemos compreender os corpos destes homens trans como algo acabado ou já produzido, mas como um elemento que está imerso num processo de transição.

Neste sentido, podemos estabelecer uma reflexão sobre a categoria discursiva 'Identidade' - a qual possui mais de $70 \%$ das evocações - com suas respectivas subcategorias discursivas. Podemos pressupor de antemão que as identidades e as transmasculinidades destes sujeitos são (re)elaboradas não somente no que diz respeito às transformações corporais, mas também a partir da sua situação 'de' e 'no' mundo; 'de' mundo a partir do seu próprio olhar e 'no' mundo a partir do olhar do outro.

Estas subcategorias discursivas foram estabelecidas de acordo com os significados atribuídos a elas, sendo analisadas em conjunto para a compreensão da categoria discursiva 'Identidade'. Assim, o processo de identificação masculina não é linear, o que corrobora com as considerações de Zambrano (2011), sendo um processo particular de cada sujeito, ocorrendo em diferentes fases da vida, a partir de diferentes vivências. Schilt e Westbrook (2009) argumentam que o que se denomina de 'fazer gênero' é um processo interacional, no qual as identidades de gênero são elaboradas, mas que em termos de mecanismo, presumem-se que derivem de uma "realidade" biológica. Para elas, devido ao fato das masculinidades e as feminilidades não serem propriedades fixas de "corpos masculinos" e "corpos femininos", as expectativas de comportamento de homens e mulheres diferem em termos temporais, e a partir de nossa compreensão, espaciais. Neste caminho, para as autoras, são as expectativas normativas do que é ser homem e do que é ser mulher que mantém a desigualdade de gênero. $\mathrm{O}$ reconhecimento enquanto 
Espaço-Corpo e a (Re)elaboração das Transmasculinidades e Identidades de

Homens Trans

pertencente ao universo masculino sempre esteve presente na trajetória de vida de alguns homens trans entrevistados, mesmo que de formas distintas (categoria discursiva 'Identidade' - subcategoria discursiva 'Ser Homem'; $28,92 \%)$ :

[...] Me via como menino, sempre fui, me identifico assim, eu não consegui também cair na real que eu era trans nessa época, não se falava nisso... uma coisa de tu se olhar pro teu corpo, e tu tentar te enxergar nos outros. Eu não conseguia me enxergar nos outros, eu não conseguia me identificar com os outros, eu não conseguia me identificar com as minas, também, ao mesmo tempo não fazia parte dos meninos, porque eles não me colocavam como parte deles, então era uma coisa assim, muito de solidão, [...] depressão, ansiedade, problemas dentro de casa... [...]. (Entrevista realizada com Homem de Gelo no dia 13 de outubro de 2017 em Porto Alegre, Rio Grande do Sul).

O processo de identificação masculina segundo as entrevistas se dá de forma "inocente" na infância, sem levar em conta os padrões de masculinidades e feminilidades estabelecidos socialmente. A partir do momento que estes homens trans crescem e atingem a puberdade, estes padrões de gênero são impostos com mais intensidade, vide as transformações naturais dos corpos:

Eu gostava muito quando eu não tinha menstruado, desenvolvimento dos seios justamente por causa dessa não identificação do corpo enquanto mulher. Acho que os piores traços começam ai na puberdade, seu rosto de desenvolver de um jeito com traços mais femininos [...] Eu achava que ia ficar de um jeito, ele sempre foi desenvolvendo de um jeito que eu não queria. [...] a partir do momento em que isso começou a marcar quem eu sou, minha identidade, com quem eu me relacionava, porque isso marca, como você se apresenta muito, quais os lugares que você pode ir, quais não, porque começa a marcar assim, qual banheiro que você usa? Quais atividades você pode fazer? [...]. (Entrevista realizada com Wolverine no dia 07 de abril de 2018 em Apucarana, Paraná).

O discurso acima evidencia as transformações do corpo a partir da puberdade e as marcações sociais que decorrem destas transformações. Assim, ao desenvolver naturalmente um corpo dito feminino, a corporeidade deste homem trans estava atrelada ao espaço, determinando quais espaços este corpo, neste caso sexuado, pode vivenciar e quais não. Estas considerações também foram evidenciadas nos estudos de Ribeiro, A. (2018). Conforme a autora, as interdições que os seus interlocutores eram sujeitos estavam atreladas aos níveis de desenvolvimento corporal, ou seja, quanto mais visível o desenvolvimento do corpo, maiores são as interdições socioespaciais. Para Silva (2013), a corporeidade sexuada está atrelada ao espaço, ao passo que possibilita determinadas ações de determinados grupos em determinados

Adelaine Ellis Carbonar dos Santos, Marcio Jose Ornat 
espaços. Por exemplo, demonstrações de afeto por casais heterossexuais são autorizadas em espaços públicos e proibidas por casais homoafetivos. Assim, conforme a autora, esta relação entre corporeidade e espaço provoca 'acolhimento, indiferença ou exclusão'.

Segundo as entrevistas, alguns homens trans se identificavam enquanto lésbicas devido a própria necessidade em se inserir socialmente em determinada categoria, enquanto outros se identificavam nesta categoria devido à pressão social. Outros ainda nunca se identificaram enquanto lésbicas. Ao afirmar uma identidade lésbica, estes homens trans realizavam uma 'tentativa' de enquadramento social, mas que não supria a real necessidade do indivíduo, como pode ser evidenciado no discurso abaixo:

[...] quando eu tava com 14 anos, assim, antes já sentia assim desconforto comigo, né. Então, eu sabia que eu curtia guria, que eu ficava... né [...] aí, sou lésbica [...]. Aí só que eu não me sentia satisfeita com essa identificação, não me identificava como lésbica [...]. (Entrevista realizada com Mancha Solar no dia 16 de fevereiro de 2017 em Ponta Grossa, Paraná).

O principal motivo da identificação anterior enquanto lésbica parte de uma necessidade de se encaixar socialmente em determinada classificação social, principalmente pelo desconhecimento da transexualidade masculina e da compreensão da distinção entre orientação sexual e identidade de gênero. Este desconhecimento da transexualidade masculina antes do processo de transição é recorrente entre os entrevistados, fruto da invisibilidade que homens trans estão suscetíveis socialmente. Alves e Moreira (2015) denunciam a ausência e a baixa representatividade de homens trans em estudos acadêmicos, bem como a invisibilidade destes sujeitos no próprio movimento LGBT+ (categoria discursiva 'Identidade' - subcategoria discursiva 'Invisibilidade'; 1,81\%). Esta afirmação corrobora com os dados que evidenciamos a partir das publicações de teses e dissertações no Catálogo da CAPES, sendo que as publicações sobre homens trans representam somente 5,17\% (21 pesquisas) do universo total de 406 pesquisas sobre transexualidades ${ }^{10}$.

Sobre a (in)visibilidade transmasculina, Broz (2017) afirma que estes sujeitos (re)elaboram suas masculinidades de formas heterogêneas e fluídas no decorrer do processo de transição, destacando as múltiplas maneiras de se tornarem visíveis e serem percebidos. Como veremos adiante, esta (in)visibilidade de homens trans também está relacionada à passabilidade dos mesmos.

A insatisfação frente à identificação lésbica é marcada por tratamentos no feminino e, principalmente, em relações afetivas e sexuais com mulheres, em que a ideia de relação homoafetiva é insuficiente, já que existe interiormente a identificação masculina. Não obstante, os homens trans que afirmaram uma identificação lésbica ante à identificação masculina, estavam sujeitos à dois

10 Levantamento de Teses e Dissertações defendidas e publicadas no Catálogo disponível no site da CAPES realizado até $1^{\circ}$ de abril de 2019 (SANTOS; CHAGAS; ORNAT, 2020). Vale ressaltar também que dentro deste universo existem pesquisadores e pesquisadoras trans, com o nome retificado ou não, à exemplo de Reidel (2013), Lanz (2014) e Oliveira (2017). 
processos: se assumir primeiramente enquanto lésbica para si mesmos e para família e amigos e, num segundo momento, se assumir enquanto homem trans. Para Broz (2017), a lesbianidade vivenciada por alguns homens trans se caracterizava enquanto uma parada ou um caminho à elaboração da masculinidade, estabelecidas através das fronteiras entre identidades. Assim, é a partir da vivência lésbica que alguns sujeitos se aproximaram do universo masculino, principalmente relacionados às vestimentas e atos socialmente masculinizados, até se perceberem enquanto homens trans.

Contudo, a autoaceitação se constitui enquanto um processo complexo, principalmente pelo desconhecimento do universo transmasculino e pela estigmatização, marginalização e o julgamento das travestilidades ligadas à prostituição. Como destacado por Ávila (2014, p. 106), "[...] a autoidentificação trans parece ser um processo longo e permeado de receios, fantasias, esperanças, contradições, tensões e conflitos, tanto na esfera privada quanto pública, até chegar ao difícil reconhecimento social do gênero desejado". Para outros, a autoaceitação enquanto homem trans é sinônimo de liberdade, ao passo que buscam o entendimento dos próprios desejos e a satisfação corporal.

O reconhecimento enquanto homem trans também é marcado pela multiplicidade de identidades e masculinidades, incluindo as masculinidades que não precisam ser (re)elaboradas mediante transformações corporais. Enquanto uma masculinidade não hegemônica, esta masculinidade é reconhecida simplesmente pelo fato de se pertencer ao universo masculino, independentemente de estar em conformidade com as normas de gênero ou não:

[...] pra mim não era só a questão do corpo, não era só uma mudança corporal, isso foi chave pra poder me assumir como homem, é que eu não estava fazendo uma afirmativa de dizer que estava no corpo errado que eu ia mudar o corpo, não era isso que eu tava dizendo. Quando me assumi como homem, eu tava dizendo, eu sou homem dessa forma, nesse corpo, agora, se eu quiser depois fazer uma modificação, ok, como qualquer outra pessoa pode fazer, mas não é isso que tá marcando, não é isso que to dizendo, to dizendo que sempre poderia ter sido tratado como homem desde sempre, não é isso que vai me marcar como homem na sociedade, então é importante, podia dizer, olha, isso pra mim podia ter sido desde a infância, já podia ter sido tratado como homem desde então, isso era importante pra mim de fazer as pessoas entenderem. (Entrevista realizada com Ciclope no dia 13 de outubro de 2017 em São Leopoldo, Rio Grande do Sul).

Isto evidencia a própria multiplicidade que as transmasculinidades possuem. De acordo com Silva (2010), ao se desconstruir o caráter essencialista dos gêneros, foi possível incluir sujeitos que são ininteligíveis à matriz cultural heterossexual e conceber a existência de múltiplas masculinidades e feminilidades. Assim, para a autora, o espaço compõe o gênero construído e desconstruído socialmente. Neste sentido, este homem 
trans poderia ter reivindicado sua masculinidade desde a infância, caso os espaços como a casa e a escola tivessem desconstruído o gênero em seu caráter essencialista, independente das transformações corporais mediante processo de transição ou não.

Entretanto, as entrevistas têm evidenciado que o processo de transição se constitui enquanto importante na medida em que há o rompimento com a feminilidade, ao passo que se reconhecem enquanto sujeitos masculinos e, posteriormente, quando começam a pleitear suas identidades e masculinidades mediante o processo de transição.

A compreensão do significado do início do processo de transição também não é linear, podendo se iniciar para alguns com a hormonioterapia, enquanto que para outros pode se iniciar na utilização do nome social, vestimentas e corte de cabelos, por exemplo. Desta forma, o processo de transição tanto pode ser entendido enquanto uma transição social primária e, posteriormente, transição corporal mediante hormônios e procedimentos cirúrgicos (categoria discursiva 'Identidade' - subcategoria discursiva 'Processo de Transição'; $13,25 \%)$ :

[...] Só que, por exemplo, em relação ao processo de transição, a única coisa que eu fiz de verdade, foi me assumir pras pessoas enquanto [nome oculto], embora eu não tivesse feito nenhuma modificação corporal, assim, sabe, eu lembro que em setembro de 2015 eu cortei o cabelo. (Entrevista realizada com Wolverine no dia 07 de abril de 2018 em Apucarana, Paraná).

[...] parte da minha transição foi busca minha assim, eu que lutei pelo meu nome... isso que tive que correr atrás do meu nome, da minha hormonização, tive que correr atrás da minha cirurgia, fiz dia 25 de agosto agora... [...] adorei o resultado, maravilhoso. [...] uma transição mais social e depois uma hormonização... [...]. (Entrevista realizada com Homem de Gelo no dia 13 de outubro de 2017 em Porto Alegre, Rio Grande do Sul).

Independentemente de como o processo de transição é entendido, ele faz parte da (re)elaboração das identidades e masculinidades destes homens trans. Para estes indivíduos, o processo de transição é um divisor de águas, sendo um processo repleto de incertezas, medos e inseguranças, mas também o ponto de partida para uma nova vida e novas vivências.

O desconhecimento da transexualidade em conjunto com o início tardio do processo de transição culmina em privações sociais e exclusões. Neste sentido, pessoas trans, incluindo homens trans, não somente estão suscetíveis à morte física, mas também à uma morte social, configurada a partir de uma mistanásia, a qual ocorre anteriormente à morte do corpo. Esta mistanásia é colocada em prática quando são negados os direitos sociais destes indivíduos antes da morte física:

Eu queria ter feito a transição antes de entrar na escola, eu acho que eu teria aproveitado muito mais o tempo na escola. [...] Eu vejo que 
Espaço-Corpo e a (Re)elaboração das Transmasculinidades e Identidades de

Homens Trans

eu perdi muitas oportunidades. [...] Eu acho que na verdade a maior privação foi afetiva, depois de uma série de outras coisas, formação e tal, mas eu não conseguia estar num espaço, tinha muita vergonha. (Entrevista realizada com Wolverine no dia 07 de abril de $2018 \mathrm{em}$ Apucarana, Paraná).

[você acha que a transição não ser feita antes fechou algumas portas?] com certeza, o processo é mais complicado. Porque se fosse antes eu já tinha terminado faz tempo, toda a mudança, já tinha meu diploma já pronto, já tinha feito toda a cirurgia, provavelmente eu estaria trabalhando hoje, tranquilamente, né, sei lá, poderia ter feito outros estudos, até feito outra faculdade.[...]. (Entrevista realizada com Fera no dia 10 de fevereiro de 2017 em Ponta Grossa, Paraná).

Esta morte social não se efetiva somente quando estes sujeitos são expulsos de casa, mas também quando lhes são negados o direito à saúde, ao trabalho, ao estudo, dentre outros espaços, incluindo também quando lhes são negadas uma infância, adolescência, vida adulta ou velhice saudáveis. Partindo desta ideia, podemos afirmar que a mistanásia também ocorre quando homens trans privam-se de imaginar um futuro para suas vidas, ou ainda quando perdem oportunidades pessoais, profissionais ou até mesmo afetivas. A morte social está presente antes da transição destes sujeitos, mas não sendo diferente depois dela, permanecendo ainda após o início da transição, segundo novas relações, principalmente atreladas à transfobia.

Evidenciamos então que o processo de transição, além de possibilitar novas vivências para estes homens trans - embora algumas constituídas pela mistanásia - também possuem uma série de elementos que se tornam alvos para a conquista da masculinidade ideal. Assim, alguns homens trans realizam ou desejam transformações corporais na busca de uma identidade masculina (categoria discursiva 'Identidade' - subcategoria discursiva 'Transformação Corporal'; 21,08\%):

Com 16 anos eu já pensava, minha projeção de futuro era eu estudar, ter minha vida e conseguir resolver o que tinha que resolver, mas não sabia o que. Ai no primeiro ano da universidade eu me percebi trans e eu: 'puxa, agora entendi as coisas que tenho que resolver'. Aí coloquei uma coisa na minha cabeça: os anos em que eu estiver dentro da universidade eu vou transicionar. [...] A partir desse momento eu vou conseguir me inserir no mundo [...]. (Entrevista realizada com Wolverine no dia 07 de abril de 2018 em Apucarana, Paraná).

[a cirurgia está marcada?] pra ano que vem... [dois anos pelo SUS?] não vou fazer pelo SUS, vou fazer particular [...] imagine esperar pelo SUS? Não tem uma data especifica, você espera... [...] até te chamarem... [...]. (Entrevista realizada com Pique no dia 11 de outubro de 2017 em Ponta Grossa, Paraná).

Adelaine Ellis Carbonar dos Santos, Marcio Jose Ornat 
O discurso acima evidencia a busca pela identidade masculina segundo as alterações corporais mediante cirurgia e hormonioterapia e a retificação de documentos. Ao ser proferida a frase "a partir desse momento eu vou conseguir me inserir no mundo", constata-se a exclusão espacial mediante ausência de pertencimento, bem como a própria morte social (mistanásia) destes sujeitos.

Neste processo de busca pela identidade masculina, evidenciamos que o fator tempo deve ser levado em consideração e que a situação econômica dos sujeitos está diretamente relacionada às conquistas dos atributos ditos masculinos de forma mais rápida ou não. $O$ fator tempo também pode ser evidenciado nas questões que envolvem a espera na fila para a realização de procedimentos pelo SUS.

A temporalidade se constitui enquanto um fator fundamental na compreensão da (re)elaboração das identidades e transmasculinidades, corroborando com os argumentos de Braz (2018), ao afirmar que as categorias 'tempo e espera' são importantes para a inteligibilidade das narrativas dos homens trans pesquisados pelo autor. Para Braz (2018), a temporalidade pode ser evidenciada no período mínimo de acompanhamento psicológico para a indicação de procedimentos cirúrgicos pela atenção especializada, pela espera da decisão judicial no processo de retificação de nome e gênero, e pela expectativa criada na mudança corporal mediante aplicação de hormônios.

Àqueles que não possuem uma situação econômica favorável para realizar os procedimentos desejáveis nas alterações de seus corpos e que também não querem esperar (ou estão esperando) para realizar tais procedimentos pelo SUS, utilizam de táticas e ferramentas para se aproximar o máximo possível ao modelo de masculinidade desejável. Uma destas táticas diz respeito à autoaplicação de hormônios para acelerar as mudanças físicas, neste caso, visíveis socialmente:

[...]Voltei a fazer academia e comecei a tomar um tal de M-drol que é um comprimido, era pra tomar 30, tomei 90, que tava criando corpo... fui parar no hospital. Dai me deu problema no figado, no rim, no intestino... deu até gastrite nervosa. Quase fui pro pau. [...] (Entrevista realizada com Homem Múltiplo no dia 09 de maio de 2017 em Maringá, Paraná).

[...] eu comprei clandestinamente [...] Então eu comprava e eu mesmo me aplicava. Ia na farmácia, pegava agulha, seringa, enfiava na coxa e já era. Fiquei 2 anos aplicando escondido da minha familia [...]. (Entrevista realizada com Pique no dia 11 de outubro de 2017 em Ponta Grossa, Paraná).

A autoaplicação de hormônios por parte de alguns homens trans é uma resposta à ansiedade e ao desejo de acelerar o processo na busca pelas características masculinas, somando-se à morosidade e burocracia por parte do SUS. A prática da autoaplicação de hormônios pode ser comum no meio trans, mas não se configura enquanto uma regra, visto que alguns homens trans entrevistados buscam outros caminhos para iniciar a hormonioterapia, seja por 
De acordo com Oliveira (2015), as mudanças corporais são evidentes já nas primeiras aplicações, mesmo não se configurando enquanto homogêneas em todos os sujeitos. Os homens trans que iniciam a hormonioterapia tem um objetivo em comum: "[...] adquirir características tidas como dos corpos masculinos, nomeadamente o tom de voz mais grave, aumento de pelos no corpo, surgimento de barba no rosto, distribuição da gordura corporal em um padrão mais masculino e incremento da musculatura" (OLIVEIRA, 2015, p. 96). A busca pela transformação corporal está baseada no fato de que em diversas interações sociais, é pouco importante os corpos privados das pessoas trans, e como se eles se "passassem" pelo seu gênero social desejado, a sua aparência, a mais próxima da desejada, é considerada uma prova de seu sexo biológico, mesmo que em encontros sexuais estas suposições tidas como certas possam ser interrompidas, suposições estas de que pessoas que se parecem mulheres tem vagina, e que as que se parecem homens tem pênis (SCHILT e WESTBROOK, 2009).

Para muitos homens trans, o início da hormonioterapia é o próprio renascimento do indivíduo, pois é a partir deste processo que as características físicas masculinas se sobressaem (pelos em variadas regiões do corpo, alterações de voz e biotipo). Contudo, é nesta etapa que as mamas podem tornar-se, então, um problema notável, pois é destacado a coexistência de atributos tanto masculinos, quanto femininos no mesmo indivíduo que deseja se afastar por completo da feminilidade. Assim, para evitar a coexistência de seios e barba, por exemplo, muitos homens trans se utilizam de faixas compressoras de seios, conhecidas como binder, mas não sem consequências para a própria saúde ${ }^{11}$ e bem estar.

As transformações dos corpos estão envolvidas em assumir riscos. Não obstante, estes riscos estão diretamente relacionados à situação econômica de cada homem trans, sendo que àqueles que possuem recursos financeiros podem optar por procedimentos cirúrgicos por vias particulares. Um destes procedimentos é a mastectomia ou mamoplastia masculinizadora, que segundo Oliveira (2015), se constitui como uma das primeiras cirurgias realizadas pelos homens trans - em alguns casos por processos judiciais junto aos seus planos de saúde para a cobertura dos procedimentos - em decorrência da demora para obtenção pela via dos serviços públicos.

Para o autor, este procedimento é designado como principal, devido a possuir um 'efeito social', visto que os seios são as únicas partes do corpo visíveis mesmo com vestimentas, podendo, assim, revelar a transexualidade. $\mathrm{O}$ fato de a transexualidade poder ser revelada mediante presença dos seios pode acarretar em constrangimentos e exclusões em determinados espaços, corroborando mais uma vez com os argumentos de Silva (2013) sobre a relação entre corporeidade e espaço, neste sentido, afetando diretamente suas vidas, seus sonhos e planos de futuro.

11 Pressão na caixa torácia, restringem a respiração, não permitem a expansão do tórax, podem causar problemas respiratórios, compressão das costelas (em casos extremos podendo levar a costelas partidas), nódoas negras, entre outras consequências. É recomendado não utilizar o binder por mais de 8 horas seguidas. Disponível em: $<$ http://transcenas.blogspot.com.br/2014/09/masterpostbinders.html $>$ Acesso em: 26 nov. 2017. 
A mastectomia se configura como um procedimento de suma importância para a (re)elaboração da masculinidade, sendo destacada como um grande desejo dos homens trans entrevistados (mais do que a própria cirurgia de transgenitalização). Portanto, a preocupação voltada às mamas pode ser compreendida na relação que elas possuem com a feminilidade, constituindose então um paradoxo entre feminilidade e masculinidade, justamente por ser visível socialmente:

[...] quando você fala que você é homem trans as pessoas pensam a primeira coisa é a genitália, né? [...] E pra nós os homens trans na verdade a mais importante é a mastectomia mesmo. Por causa que a mama é a que mais aparece [...] muitos meninos preferem fazer só a questão da mastectomia e pronto... e retirada do útero, ovários, devido os hormônios não ficar ali competindo, estrogênio com testosterona, e também risco de câncer [...]. (Entrevista realizada com Fera no dia 10 de fevereiro de 2017 em Ponta Grossa, Paraná).

Conforme Silva (2013), a fluidez dos corpos e suas transformações presentes nas concepções de geógrafas e geógrafos feministas possibilitaram o rompimento da linearidade entre gênero e anatomia genital. Diante disto, a histerectomia, que se configura enquanto um procedimento cirúrgico para a retirada de útero e ovários, se constitui para Oliveira (2015), como um recurso secundário, vide o fluxo menstrual cessar após o início da hormonioterapia. Todavia, destacamos que, mesmo que a mamoplastia seja o primeiro procedimento desejável, não quer dizer que estes homens trans em algum momento de suas vidas não desejem a cirurgia de neofaloplastia. Assim, a multiplicidade envolvendo a (re)elaboração das identidades e masculinidades de homens trans é constatada quando evidenciamos que nem todos os sujeitos possuem a necessidade de incluir no processo de uma identidade masculina todos as características atribuídas socialmente ao universo masculino:

[...] Eu não sinto a necessidade de usar nenhum meio disso assim pra volume essas coisas, né? [...]. (Entrevista realizada com Fera no dia 10 de fevereiro de 2017 em Ponta Grossa, Paraná).

[...] na verdade eu parei a hormonização desde o início desse ano porque eu quis, né, só pra ver como fica, porque acho que é uma coisa que posso fazer na minha vida pra ver como vou lidar [...]. (Entrevista realizada com Ciclope no dia 13 de outubro de 2017 em São Leopoldo, Rio Grande do Sul).

O processo que envolve a hormonioterapia também é múltiplo, pois difere de homem trans para homem trans, podendo, inclusive, ser interrompido. Neste sentido, o processo de transição também pode ser concluído quando o indivíduo se sente satisfeito com as transformações corporais adquiridas, criando possibilidades de novas experiências corporais mediante interrupção da hormonioterapia, por exemplo. Para Silva (2013, p. 35), "o corpo não é algo que pertence ao ser humano, mas é o próprio ser, que ganha existência social 
por meio da experiência corpórea. O corpo é também lugar onde um ser humano desenvolve a noção de limite com os outros seres e a forma que esse corpo se apresenta e ao mesmo tempo é percebido pelos outros, varia de acordo com o espaço e o tempo que o compõem".

Um ponto importante de ser ressaltado é que o processo de transição e os procedimentos cirúrgicos realizados facilitavam a retificação dos documentos pela via judicial (categoria discursiva 'Identidade' - subcategoria discursiva 'Nome Social/Retificado'; 3,01\%). Assim, a retificação do nome e gênero em documentos oficiais também está inserida na (re)elaboração das identidades. Anteriormente ao Provimento $\mathrm{n}^{\mathrm{0}} 73 / 2018$, as pessoas transexuais e travestis eram obrigadas a entrar com ações judiciais para angariar a retificação do prenome e gênero no registro civil. Este processo, segundo Gherini et al. (2019), além de possuir valores altos, demandava tempo de espera para a sentença judicial - assim como afirmado por Braz (2018) sobre as categorias tempo e espera - bem como situações constrangedoras e abusivas durante o processo judicial.

Outra questão que está diretamente relacionada a (re)elaboração das identidades e masculinidades destes homens trans se refere à passabilidade que possuem (categoria discursiva 'Identidade' - subcategoria discursiva 'Passabilidade'; 2,41\%). Embora o termo não seja bem aceito para alguns entrevistados, é importante ressaltar que esta passabilidade possui duas faces: a primeira relacionada à passabilidade enquanto homem cis, o que dá subsídios para não sofrer transfobia; e a segunda relacionada à invisibilidade de homens trans, invisibilidade esta exercida muitas vezes por eles mesmos, a partir do medo:

[você vê a passabilidade como privilégio?] talvez seja privilégio se você olhar em relação ao menino trans que não tenha essa passabilidade, que por exemplo, no início que eu não tinha essa passabilidade, nem gosto muito dessa palavra, mas vou falar, eu tinha que ficar reafirmando minha identidade como homem e tudo mais, eu tinha que ficar batendo na tecla [...] e hoje em dia as pessoas só olham pra mim e se eu não falar, elas não vão saber [...]. (Entrevista realizada com Skype no dia 16 de outubro de 2017 em Pelotas, Rio Grande do Sul).

Como evidenciado, a passabilidade dá subsídio para o reconhecimento enquanto homem, na medida em que não há a necessidade de reafirmar sua identidade masculina socialmente, mas sendo garantida paulatinamente por estes sujeitos. Como destacado por Lanz (2014), a passabilidade diminui as chances de sofrer transfobia, mas esta ideia não pode ser constituída de forma ingênua. A passabilidade protege da transfobia, mas não garante que a transfobia não seja praticada quando a transexualidade é colocada em evidência, tampouco não isenta presenciar práticas transfóbicas realizadas por terceiros.

Ainda, pelo desconhecimento da transexualidade masculina, alguns homens trans se identificaram anteriormente enquanto lésbicas, como já evidenciado, resultando em uma invisibilidade destes sujeitos, seja pelo próprio universo 
trans, pela sociedade em geral, ou até por eles mesmos, mediante a passabilidade. Conforme Broz (2017), sendo as masculinidades múltiplas, também são múltiplas as maneiras destes sujeitos se tornarem visíveis. Assim, ao buscar uma masculinidade ideal do que é ser homem socialmente - leia-se, conquistar a passabilidade - "es decir, mientras que se visibiliza lo masculino dominante se invisibiliza lo trans. [...] Es en esa tensión, entre no ser reconocido como una masculinidad o pasar inadvertido, que se delinean las trayectorias de las transmasculinidades" (BROZ, 2017, p. 241).

Para a autora, esta tensão de (in)visibilidade (passabilidade) não está relacionada simplesmente na oposição entre 'benefício e prejuízo', mas na compreensão dos contextos socioespaciais que estes sujeitos estão inseridos. Assim, conceber uma perspectiva interseccional nos parece interessante neste momento (categoria discursiva 'Identidade' - subcategoria discursiva 'Interseccionalidade'; 1,81\%). Como já evidenciado, as identidades e masculinidades são interseccionadas, o que não seria diferente na constituição das identidades masculinas por parte destes homens trans. Assim, a (re)elaboração identitária das transmasculinidades destes sujeitos também está relacionada aos privilégios que alguns possuem:

Eu perco e ganho privilégios. Perdi por ser negro. Se você nasce negro, você já nasce perdendo privilégios, um monte de privilégios. Porém, ganhei porque eu tenho uma vida financeira boa. [...]. (Entrevista realizada com Pique no dia 11 de outubro de 2017 em Ponta Grossa, Paraná).

Podemos evidenciar que a compreensão das identidades e masculinidades somente são possíveis se levarmos em consideração a interseccionalidade entre categorias identitárias vivenciadas por cada sujeito. Desta forma, é mediante a interseccionalidade que determinado homem trans irá sofrer mais ou menos violência em determinado contexto. Para Silva (2010), a interseccionalidade como um campo metodológico, considera a existência simultânea de múltiplas categorias sociais e as articulações entre elas, mediante a fluidez e instabilidade das identidades, de acordo com o contexto espaço-temporal, possibilitando em diferentes relações.

$\mathrm{Na}$ busca por uma identidade masculina, o apoio por parte da família no processo de transição, na hormonioterapia, na escolha do nome, nos recursos financeiros para procedimentos cirúrgicos, acompanhamento em psicólogos ou consultas médicas, etc, contribuem para que os sujeitos se sintam seguros e acolhidos, facilitando o processo de autoaceitação enquanto homem trans e auxiliando no enfrentamento da transfobia. Assim, a categoria discursiva 'Relações Familiares' (6,63\%) da categoria espacial 'Corpo' pode auxiliar na compreensão da (re)elaboração das identidades e transmasculinidades.

Neste contexto, a instituição familiar se constitui então enquanto uma instância social que está atrelada ao bem estar biopsicossocial destes sujeitos. É nas relações familiares que as normas de gênero são ensinadas e apreendidas desde a infância, não obstante, atuando em conjunto com o Estado, igreja, medicina, por meio da cisheteronormatividade, fabricando corpos sexuados (BENTO, 2003). A partir destas normas de gênero que a identificação 
enquanto homem trans nas relações familiares é marcado, tanto por repreensões quanto por resistências (OLIVEIRA, 2015), mas também, podemos evidenciar nos discursos dos nossos interlocutores que as relações familiares podem, além disso, subverter as normas de gênero, mediante assistência por parte da instituição familiar, mesmo que num primeiro momento, tais familiares sintam medo ou não concordem com o processo de transição.

Como evidenciado, este apoio, principalmente financeiro, pode estar relacionado também à busca mais rápida de atributos masculinos desejados segundo a realização de procedimentos cirúrgicos, consultas médias e psicológicas, além da hormonioterapia, sendo mais uma vez articulado com a categoria de tempo e espera proposto por Braz (2018). Infelizmente, este apoio tanto moral quanto financeiro por parte de familiares não é uma realidade para todos os homens trans, sendo que pensamentos envolvendo a expulsão de casa ao reivindicar a identidade de gênero estão no imaginário de alguns dos entrevistados.

A atividade da prostituição é tida como uma possibilidade de sobrevivência caso não houvesse esta aceitação da transexualidade por parte de familiares ou por necessidades financeiras, sendo que um dos entrevistados já praticou a atividade da prostituição. Entretanto, os homens trans que concebem a prostituição como uma forma de sobrevivência, mas que não a praticam, relatam uma dificuldade em aceitar seus corpos sendo tocados por terceiros para fins exclusivamente econômico-sexuais (categoria espacial 'Corpo' categoria discursiva - 'Prostituição'; 3,61\%).

[Você já viveu da atividade da prostituição?] Não, mas queria. [necessidade?] sim, mas acho que é uma coisa que não consigo. Eu tenho a necessidade, eu penso muito nisso, mas acho que não vou. Eu tenho umas questões com meu próprio corpo, não de achar ruim meu corpo, mas de não aceitar outras pessoas tocando meu corpo, questões da minha infância, enfim, que não foram muito legais. [...]. (Entrevista realizada com Homem de Gelo no dia 13 de outubro de 2017 em Porto Alegre, Rio Grande do Sul).

Silva (2011) afirma que não só existe uma escassez de referencial teórico acerca da prostituição masculina, mas também que são autores homens que teorizaram grande parte do universo que abrange o fenômeno da prostituição feminina. Não obstante, existe uma ausência no que tange a literatura brasileira sobre a prostituição transmasculina, ao passo que referenciais teóricos sobre prostituição transfeminina são encontrados em pelo menos 14 títulos de pesquisas científicas brasileiras publicadas no Catálogo de Teses e Dissertações da CAPES. Assim, torna-se urgente a compreensão sobre o fenômeno da prostituição transmasculina, suas dinâmicas e articulações.

O que nos chama atenção nesta categoria discursiva é sua relação com a experiência tátil e os corpos destes sujeitos. Conforme afirma Silva M. (2018), os relacionamentos afetivo-sexuais podem ser compreendidos enquanto sinônimos de 'segurança e conforto'. Partindo desta ideia, podemos pressupor que as relações para fins econômico-sexuais se configuram enquanto o oposto 
desta ideia de proteção, na qual estes homens trans estariam vulneráveis, por exemplo, não suportando que outras pessoas toquem seus corpos.

Estas considerações podem ser melhor compreendidas com a categoria discursiva 'Sentimento' (12,65\%), uma vez que existe o sentimento de inferioridade nestes indivíduos, justamente no que diz respeito aos relacionamentos afetivo-sexuais. Assim, alguns homens trans sentem-se inferiores em relação aos homens cis ou possuem medo de revelar sua transexualidade para seus potenciais parceiros ou parceiras:

[...] eu fiquei tenso em não conseguir dizer pras pessoas que eu era trans, sabe, tipo assim, no início eu ficava com algumas pessoas aqui, daí as pessoas não sabiam que eu era trans e aí, eu ficava meio desconfortável... relacionado ao lado afetivo. [...]. (Entrevista realizada com Skype no dia 16 de outubro de 2017 em Pelotas, Rio Grande do Sul).

Em sua pesquisa com homens trans, Ávila (2014) evidenciou que os relacionamentos estáveis destes sujeitos e outras pessoas estavam atrelados ao nível de segurança que possuem das suas masculinidades. Assim, para a autora, alguns homens trans possuem dificuldades em relacionamentos afetivosexuais frente à elaboração ainda insatisfeita de seus corpos masculinos.

Além disso, a categoria discursiva 'Sentimento' torna-se relevante para a compreensão da constituição das identidades e masculinidades destes homens trans, pois é através dela que constatamos que não podemos conceber somente o corpo físico, mas que é imprescindível compreendermos como as questões psicológicas afetam a (re)elaboração da identidade masculina pleiteadas por estes sujeitos.

O processo de autoaceitação, processo de transição, processo de assumir a transexualidade socialmente está repleto de sentimentos distintos além da insegurança, mas também da alegria, do medo, da angústia, da culpa e do sofrimento. Neste caso, a culpa se constitui enquanto um sentimento que está presente na vida destes homens trans, principalmente relacionadas ao processo de autoaceitação, afetando-os de diferentes maneiras, podendo chegar à quadros depressivos e tentativas de suicídios. Assim, a categoria discursiva 'Doença' $(4,82 \%)$ da categoria espacial 'Corpo', evidencia alguns discursos referentes à depressão e ideação suicida destes homens trans:

[...] eu sou borderline, tive ansiedade, depressão, várias tentativas de suicídio, tanto na infância quanto na adolescência [...] que eu também, por conta do meu corpo de querer me machucar, por conta de genital, peito, eu olhava assim, era criança, peito pouquinho assim, a partir dos 18, sabe? Mas eu tinha muito medo de ver eles crescendo, ficava todo tempo, criança olhando e dando... 'eu tenho que aproveitar isso aqui máximo agora, que depois talvez cresça e eu vá ter um corpo que eu não vou suportar, esses aspectos... [...]. (Entrevista realizada com Homem de Gelo no dia 13 de outubro de 2017 em Porto Alegre, Rio Grande do Sul). 


\section{Considerações Finais}

Este artigo teve por objetivo compreender o movimento de (re)elaboração das transmasculinidades e das identidades a partir da corporeidade de homens trans. Evidenciamos a necessidade de considerar que tanto o espaço quanto as identidades (de gênero) e os corpos são (re)elaborados em um processo aberto e contínuo. Neste sentido, consideramos não somente os espaços, as identidades e as transmasculinidades (re)elaborados num devir, mas também que os corpos estão em constantes transformações, não sendo um produto acabado ou produzidos a priori. São corpos em transições.

Uma vez que o recorte do grupo é heterogêneo e a fluidez entre identidades é um elemento constituinte das mesmas, constatamos que as novas identidades - transitórias e instáveis, são (re)elaboradas a todo instante no espaço-tempo, mediante as relações de poder. Não há uma maneira exclusiva de ser homem trans pertencendo à uma identidade já elaborada, mas a uma multiplicidade de (re)elaborações identitárias possíveis. Do mesmo modo, são múltiplas as formas de (re)elaboração das masculinidades, sendo a corporeidade um elemento neste processo. Diante deste cenário, em que a corporeidade dos

12 OMS. Organização Pan-Americana da Saúde. Folha Informativa - Suicídio. Disponível em: $<$ https://www.paho.org/bra/index.php?option=com_content\&view=article\&id=5671: folhainformativa-suicidio\&Itemid=839>. Acesso em: 22 dez. 2019. 
homens trans torna-se importante para a elaboração das suas masculinidades, é relevante nos questionar se seria a busca pela passabilidade o primeiro passo rumo à uma masculinidade hegemônica pelos homens trans?

Respondendo ao questionamento, ao contrário do que concluiu Ávila (2014) de que as transmasculinidades - enquanto uma masculinidade sem pênis - são desestabilizadoras de masculinidades hegemônicas, pensamos que - além do que Ávila (2014) propôs - as transmasculinidades, a partir da busca por uma passabilidade condizente com os padrões cisnormativos, reiteram ainda mais as masculinidades hegemônicas. A partir das afirmações de Schilt e Westbrook (2009), podemos também evidenciar que as pessoas trans, que tem reivindicado a sua categoria de gênero, têm sido desafiadas por questões baseadas na genitália, que por sua vez estão relacionadas a heterossexualidade das pessoas cisgênero. Para elas, o funcionamento da heterossexualidade demanda um sistema sexual binário, que é baseado na atração entre corpos diferentes, definidos como locais distintos e opostos. Assim, nesta argumentação, é a presunção que a heterossexualidade e a identidade de gênero descendem da genitália que produz a heteronormatividade, mesmo que na grande maioria das interações sociais as genitálias não estejam envolvidas. Portanto, a questão é a busca do padrão de masculinidade cisnormativo.

Ao levarmos em consideração que os corpos são tanto objetos quanto agentes da prática social (CONNELL; MESSERSCHMIDT, 2013), a partir das entrevistas realizadas para a elaboração desta discussão, podemos afirmar que os homens trans não somente desestabilizam, mas também contribuem para a constituição da masculinidade hegemônica, que simultaneamente os exclui socialmente.

Neste sentido, é preciso considerar uma perspectiva interseccional para a compreensão destas diferentes relações, bem como destacar a passabilidade enquanto uma categoria de análise, na medida em que estes sujeitos não só desestabilizam como também contribuem para a constituição da masculinidade hegemônica mediante sua corporeidade.

\section{Referências}

ALVES, Maria de Fátima Paz. "Masculinidade/s: considerações a partir da leitura crítica de alguns textos que focalizam homens". Revista Ártemis, n. 3 p. 2-14, 2005.

ALVES, Cláudio Eduardo Resende; MOREIRA, Maria Ignez Costa. "Do uso do nome social ao uso do banheiro: (trans)subjetividades em escolas brasileiras". Quaderns de Psicologia, v. 17, n. 3, p. 59-69, 2015.

ÁVILA, Simone Nunes. FTM, transhomem, homem trans, trans, homem: a emergência de transmasculinidades no Brasil contemporâneo. 2014. Tese (Doutorado em Ciências Humanas) - Programa de Pós-graduação Interdisciplinar em Ciências Humanas, UFSC, Florianópolis - SC.

BARDIN, Laurence. Análise de Conteúdo. Lisboa: Edições 70, 1977. 
Espaço-Corpo e a (Re)elaboração das Transmasculinidades e Identidades de

Homens Trans

BENTO, Berenice. "Transexuais, corpos e próteses". Labrys: Estudos Feministas, n. 4, ago./dez. 2003.

BOTTON, Fernando Bagiotto. "As masculinidades em questão: uma perspectiva de construção teórica". Revista Vernáculo, n.19 e 20, p. 109-120, 2007.

BRAZ, Camilo. “'Eu já tenho nome' - itinerários de homens trans em busca de respeito". Habitus, v. 16, n. 1, p. 162-176, 2018.

BROZ, Mariana Álvarez. "Las paradojas de la (in)visibilidad. trayectorias de vida de las personas transmasculinas en la Argentina contemporánea". Horizontes Antropológicos, ano 23, n. 47, p. 227-258, 2017.

BUTLER, Judith. Problemas de Gênero. Feminismo e Subversão da Identidade. Rio de Janeiro: Civilização Brasileira, 2003.

CASTELLS, Manuel. O poder da identidade. São Paulo: Paz e Terra, 1999 [1997].

CONNELL, Raewyn. Masculinidades. México: Universidad Nacional Autónoma de México, 2003.

CONNELL, Raewyn. Gender. Cambridge: Polity Press, 2002.

CONNELL, Raewyn. "Políticas da Masculinidade". Educação e Sociedade, v. 20, n. 2, p. 185-206, 1995.

CONNELL, Raewyn. Gender \& power. Berkeley: University of California Press, 1987.

CONNELL, Raewyn W.; MESSERSCHMIDT, James W. "Masculinidade hegemônica: repensando o conceito". Estudos Feministas. Florianópolis, v. 21, n. 1, p. 241-282, jan./abr. 2013.

DUBAR, Claude. A Socialização: construção das identidades sociais e profissionais. Porto: Porto editora, 1997. (Tradução: Annette Pierrette R. Botelho e Estela Pinto Ribeiro Lamas).

FIALHO, Fabrício Mendes. "Uma Crítica ao Conceito de Masculinidade Hegemônica". In: Seminário Internacional Fazendo Gênero. VII Fazendo Gênero, Florianópolis. Anais... (Seminário Internacional Fazendo Gênero). Florianópolis: UFSC. 2006. p. 1-7. Disponível em: $<$ http://www.wwc2017.eventos.dype.com.br/fg7/artigos/E/Edilane_Bertelli_09 .pdf>. Acesso em 27 nov. 2019.

FOUCAULT, Michel. História da Sexualidade I: A Vontade de Saber. Rio de Janeiro: Grall, 1988. 
Espaço-Corpo e a (Re)elaboração das Transmasculinidades e Identidades de

Homens Trans

GARFINKEL, Harold. Studies in ethnomethodology. Englewood Cliffs, NJ: Prentice Hall, 1967.

GHERINI, Pamela Michelena de Marchi; VALENTIM, Giovanna; BENEVIDES, Bruna; DAIER, Felipe Brandão. Guia para retificação do registro civil de pessoas não-cisgêneras. 2019. Disponível em $<$ https://baptistaluz.com.br/wpcontent/uploads/2019/08/Guia_retificacao_genero-V10-1.pdf $>$. Acesso em: 2 nov. 2019.

HALL, Stuart. A identidade cultural da pós-modernidade. $10^{\mathrm{a}}$ ed. Rio de Janeiro: DP\&A editora, 2005 [1992].

JANUÁRIO, Soraya Barreto. Masculinidades em (re)construção: Gênero, Corpo e Publicidade. Covilhã: Editora LabCom.IFP, 2016.

KIMMEL, Michael S. "A produção simultânea de masculinidades hegemônicas e subalternas". Horizontes Antropológicos, ano 4, n. 9, p. 103117, out. 1998.

LANZ, Letícia. O corpo da roupa: a pessoa transgênera entre a transgressão e a conformidade com as normas de gênero. 2014. Dissertação (Mestrado em Sociologia) - Programa de Pós-graduação em Sociologia, UFPR, Curitiba - PR.

MASSEY, Doreen; KEYNES, Milton. "Filosofia e Política da Espacialidade: algumas considerações”. GEOgraphia, ano 6, n. 12, p. 7-23, 2004.

MATOS, Marlise. Reinvenções do Vínculo Amoroso: Cultura e Identidade de Gênero na Modernidade Tardia. Belo Horizonte: UFMG, 2000.

OLIVEIRA, André Lucas Guerreiro. "Somos quem podemos ser": os homens (trans) brasileiros e o discurso pela (des)patologização da transexualidade. 2015. Dissertação (Mestrado em Ciências Sociais) Programa de Pós-graduação em Ciências Sociais, UFRN, Natal - RN.

OMS. Prevenção do suicídio: um recurso para conselheiros. Departamento de Saúde Mental e de Abuso de Substâncias. 2006. Disponível em: $<$ https://www.who.int/mental_health/media/counsellors_portuguese.pdf $>$.

Acesso em: 22 dez. 2019.

RIBEIRO, Andressa de Freitas. Experiências transmasculinas: o limiar entre corpo, gênero e desejo na constituição de um sentido de si. 2018. Tese (Doutorado em Ciências Sociais) - Programa de Pós-graduação em Ciências Sociais, UFBA, Salvador - BA.

SANTOS, Adelaine Ellis Carbonar dos Santos. Vivências transmasculinas 
Espaço-Corpo e a (Re)elaboração das Transmasculinidades e Identidades de

Homens Trans

em espaços educacionais de nível superior do sul do Brasil e a multiplicidade espacial. 2020. Tese (Doutorado em Geografia) - Programa de Pós-graduação em Geografia, UEPG, Ponta Grossa- PR.

SANTOS, Adelaine Ellis Carbonar dos Santos; CHAGAS, Bruna Iara Lorian; ORNAT, Marcio Jose. "A produção científica brasileira sobre travestilidades e transexualidades: da doença à resistência”. Revista Terr@ Plural, v. 14, p. 119, 2020.

SCHIPPERS, Mimi. Recovering the feminine other: Masculinity, femininity, and gender hegemony. Theory \& Society, v. 36, n. 1, p. 85 - 102, 2007.

SCHILT, Kristen; WESTBROOK, Laurel. "Gender Normals", Transgender People, and the Social Maintenance of Heterosexuality. Gender \& Society, v. 23, n. 4, p. $440-464,2009$.

SIGUSCH, Volkmar. Die Transsexuellen und unser nosomorpher Blick. Teil I: Zur Enttotalisierung des Transsexualismus [Transsexuals and our nosomorphic view. Part I: The detotalization of transsexualism]. Z. Sexualforsch, v. 4, p. 225 - 256, 1991a.

SIGUSCH, Volkmar. Die Transsexuellen und unser nosomorpher Blick. Teil II: Zur Entpathologisierung des Transsexualismus [Transsexuals and our nosomorphic view. Part II: The de pathologization of transsexualism] . Z. Sexualforsch, v. 4, p. 309 - 343, 1991 b.

SIGUSCH, Volkmar. Geschlechtswechsel [Sex Changes]. Hamburg: Rotbuch, 1995a.

SIGUSCH, Volkmar. Transsexueller Wunsch und zissexuelle Abwehr [Transsexual desire and cissexual defense]. Psyche, v. 49, p. 811 - 837, 1995 b.

SIGUSCH, Volkmar. The Neosexual Revolution. Archives of Sexual Behavior, v. 27, n. 4, p. 331 - 359, 1998.

SILVA, Joseli Maria. "Corpo, corporeidade e espaço na análise geográfica". In: HEIDRICH, Álvaro Luiz; COSTA, Benhur Pinós da; PIRES, Cláudia Luisa Zeferin. Maneiras de ler geografia e cultura. Porto Alegre: Compasso Lugar Cultura, p. 28-36, 2013.

SILVA, Joseli Maria. "Geografias feministas, sexualidades e corporalidades: desafios às práticas investigativas da Ciência Geográfica”. Espaço e Cultura, n. 27, p. 39-55, jan./jun. de 2010.

SILVA, Joseli Maria; ORNAT, Marcio Jose. "Corpo como espaço: um desafio à imaginação geográfica”. In: PIRES, Cláudia Zeferino, HEIDRICH, Álvaro Luiz; COSTA, Benhur Pinós da. Plurilocalidades do sujeito: representações e ações no território. Porto Alegre: Compasso Lugar-Cultura, p. 56-75, 2016.

Adelaine Ellis Carbonar dos Santos, Marcio Jose Ornat 
Espaço-Corpo e a (Re)elaboração das Transmasculinidades e Identidades de

Homens Trans

SILVA, José Maurício da. "Prostituição masculina: um destino pulsional?". Polêm!ca, v. 10, n. 1, p. 161-181, jan./mar. 2011.

SILVA, Mariana Furtado. Trajetórias Trans: apoio social e relações afetivosexuais de transexuais. 2018. Dissertação (Mestrado em Psicologia) Programa de Pós-graduação em Psicologia, USP, Ribeirão Preto - SP.

SILVA, Tomaz Tadeu da. "A produção social da identidade e da diferença". In: SILVA, Tomaz Tadeu da. Identidade e diferença: a perspectiva dos estudos culturais. Petrópolis: Vozes, 2000.

WELZER-LANG, Daniel. "A construção do masculino: dominação das mulheres e homofobia". Revista Estudos Feministas, v. 9, n. 2, p. 460-482, 2001.

WOODWARD, Kathryn. "Identidade e diferença: uma introdução teórica e conceitual". In: SILVA, Tomaz Tadeu da. Identidade e diferença: a perspectiva dos estudos culturais. Petrópolis: Vozes, 2000.

ZAMBRANO, Elizabeth. "Transexuais: identidade e cidadania". In: VENTURI, Gustavo; BOKANY, Vilma. (Org.). Diversidade sexual e homofobia no Brasil. São Paulo: Editora Fundação Perseu Abramo, p. 97107, 2011.

\section{Contribuição de Autoria / Contribución de autoría}

Adelaine Ellis Carbonar dos Santos: Conceituação, Análise Formal, Investigação, Metodologia, Escrita (primeira redação).

Marcio Jose Ornat: Conceituação, Análise Formal, Escrita (revisão e edição).

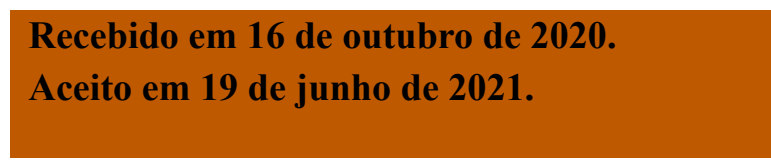

Adelaine Ellis Carbonar dos Santos, Marcio Jose Ornat 